\title{
MSANTD1 Gene
}

National Cancer Institute

\section{Source}

National Cancer Institute. MSANTD1 Gene. NCI Thesaurus. Code C140176.

This gene may be involved in both DNA binding and chromatin remodeling. 